\title{
Do mites phoretic on elm bark beetles contribute to the transmission of Dutch elm disease?
}

\author{
John C. Moser • Heino Konrad • Stacy R. Blomquist • \\ Thomas Kirisits
}

Received: 9 July 2009 /Revised: 1 October 2009 /Accepted: 19 November 2009 /Published online: 5 December 2009

(C) US Government 2009

\begin{abstract}
Dutch elm disease (DED) is a destructive vascular wilt disease of elm (Ulmus) trees caused by the introduced Ascomycete fungus Ophiostoma novo-ulmi. In Europe, this DED pathogen is transmitted by elm bark beetles in the genus Scolytus. These insects carry phoretic mites to new, suitable habitats. The aim of this study was to record and quantify conidia and ascospores of O. novo-ulmi on phoretic mites of the three elm bark beetle species Scolytus multistriatus, Scolytus pygmaeus, and Scolytus scolytus. Spores of O. novo-ulmi were found on four of the ten mite species phoretic on Scolytus spp. These included Elattoma fraxini, Proctolaelaps scolyti, Pseudotarsonemoides eccoptogasteri, and Tarsonemus crassus. All four species had spores attached externally to their body surfaces. However, T. crassus carried most spores within its sporothecae, two paired pocket-like structures adapted
\end{abstract}

J. C. Moser $(\bowtie) \cdot$ S. R. Blomquist

Southern Research Station, USDA Forest Service,

2500 Shreveport Highway,

Pineville, LA 71360, USA

e-mail: johnmoser@fs.fed.us

H. Konrad • T. Kirisits

Institute of Forest Entomology, Forest Pathology,

and Forest Protection (IFFF),

Department of Forest and Soil Sciences,

University of Natural Resources and Applied Life Sciences,

Vienna (BOKU),

Hasenauerstraße 38,

1190 Vienna, Austria

Present Address:

H. Konrad

Unit of Gene Conservation and Nurseries,

Department of Genetics, Federal Research and Training Centre

for Forests, Natural Hazards and Landscape (BFW),

Hauptstraße 7,

1140 Vienna, Austria for fungal transmission. Individuals of Pr. scolyti also had $O$. novo-ulmi conidia and ascospores frequently in their digestive system, where they may remain viable. While E. fraxini and P. eccoptogasteri rarely had spores attached to their bodies, large portions of Pr. scolyti and T. crassus carried significant numbers of conidia and/or ascospores of O. novo-ulmi. P. scolyti and T. crassus, which likely are fungivores, may thus contribute to the transmission of O. novo-ulmi, by increasing the spore loads of individual Scolytus beetles during their maturation feeding on twigs of healthy elm trees, enhancing the chance for successful infection with the pathogen. Only $S$. scolytus, which is the most efficient vector of $O$. novo-ulmi in Europe, carried high numbers of Pr. scolyti and T. crassus, in contrast to $S$. multistriatus and S. pygmaeus, which are known as less efficient vectors. The high efficiency of S. scolytus in spreading Dutch elm disease may be partly due to its association with these two mites and the hyperphoretic spores of $O$. novo-ulmi they carry.

Keywords Ulmus · Ophiostoma novo-ulmi · Scolytus spp. Scolytinae - Proctolaelaps scolyti Tarsonemus crassus. Phoresy

\section{Introduction}

Ophiostoma novo-ulmi (Ascomycota, Ophiostomatales) is the causal agent of Dutch elm disease (DED), a lethal vascular wilt disease of elm species (Ulmus spp.) in Europe, parts of Asia, and North America (Brasier 1991). Since their introduction in the 1940s, into areas where they are not native, the two subspecies of this fungus, O. novo-ulmi ssp. novo-ulmi and ssp. americana and their hybrids have been causing a second pandemic of DED, which has led to enormous damage to 
populations of susceptible elm species (Brasier 1991, 2000; Brasier and Kirk 2001; Konrad et al. 2002; Brasier et al. 2004). Although the native range of $O$. novo-ulmi is still unknown, it is suspected that the fungus originated from mountainous areas of Southern Asia, possibly somewhere in the Himalayas or adjacent regions (Brasier 2000).

O. novo-ulmi is one of the best known examples of a tree pathogen vectored by insects, particularly bark beetles (Coleoptera, Curculionidae, Scolytinae). In Europe and Asia, the fungus is transmitted by various native elm bark beetles in the genus Scolytus, while in North America Scolytus multistriatus, introduced from Europe, and the native elm bark beetle Hylurgopinus rufipes serve as vectors of the pathogen (Lanier and Peacock 1981; Webber 2000, 2004). Other than xylomycetophagous ambrosia beetles and some phloeomycetophagous bark beetles, Scolytus species on elm lack mycangia, specialized organs in the integument of the beetles that serve for the storage, transport, and transmission of fungal spores (Six 2003; Kirisits 2004). In contrast, elm bark beetles carry ascospores and conidia of $O$. novo-ulmi on the body surface and in the gut (Fransen 1939; Lanier and Peacock 1981; Webber and Brasier 1984; Webber and Gibbs 1989).

Transmission of $O$. novo-ulmi and wound inoculation of the pathogen onto its hosts occur during maturation feeding of recently emerged, sexually immature beetles on the bark of twigs and in twig crotches in the crown of healthy elm trees (Fransen 1939; Webber and Brasier 1984; Webber and Gibbs 1989). Trees succumbing due to DED are subsequently infested by Scolytus bark beetles that breed in the phloem of the stem and branches. The insects initiate characteristic breeding systems in the phloem and partly also on the sapwood surface consisting of female and larval galleries as well as pupal chambers, where the larvae pupate and turn to immature beetles (Lanier and Peacock 1981). In the pupal chambers, juvenile beetles are contaminated with ascospores and conidia of the DED pathogen prior to emergence and eventually are able to infect healthy elm trees (Fransen 1939; Webber and Brasier 1984; Webber and Gibbs 1989).

Scolytus species vary greatly in their effectiveness as vectors of O. novo-ulmi. The larger Scolytus species, in particular Scolytus scolytus, are considered to be more effective vectors than smaller species such as $S$. multistriatus and Scolytus pygmaeus (Webber and Brasier 1984; Webber and Gibbs 1989; Webber 1990, 2000). The efficiency of Scolytus spp. as vectors of O. novo-ulmi is largely determined by the kind of breeding material and the position of pupal chambers in the bark of elm trees (Webber and Brasier 1984; Webber and Gibbs 1989; Webber 1990, 2000). S. scolytus usually breeds in thick bark of elm stems and branches and commonly pupates in the moist inner bark, which is conducive for profuse sporulation of O. novo-ulmi. High loads of spores are therefore often acquired by young $S$. scolytus beetles. Conditions for acquisition of fungal inoculum are less favorable for the smaller elm scolytines usually breeding in thinner bark that dries out more quickly. They also pupate more often in the drier outer bark where sporulation of $O$. novo-ulmi is sparser than in the inner bark.

Bark beetles are known to be commonly associated with phoretic mites that use the insects for transportation to new, suitable habitats (Bridges and Moser 1983; Moser and Bogenschütz 1984; Pernek et al. 2008). The feeding habits and ecological roles of mites are diverse. Mites phoretic on bark beetles include beetle parasitoids, insect and nematode predators, fungivores, and omnivores (Moser et al. 1978; Kinn 1983; Lombardero et al. 2000, 2003; Pernek et al. 2008). These arthropods are also involved in complex symbiotic interactions with bark beetles, fungi, especially including ophiostomatoid species (Ophiostoma spp. and Ceratocystopsis spp.), and their host trees (Klepzig et al. 2001; Kirisits 2004; Hofstetter et al. 2006). Interactions between the various partners range from mutualism, commensalism to antagonism (Klepzig et al. 2001; Hofstetter et al. 2006). Some mite species on conifers are involved in the transmission of tree pathogens, mycangial symbionts, and fungal antagonists of bark beetles (Moser et al. 1995; Lombardero et al. 2000, 2003; Klepzig et al. 2001; Kirisits 2004; Hofstetter et al. 2006). Tarsonemus species even possess specialized, paired, pocket-like structures, called sporothecae, in which spores of ophiostomatoid fungi are deposited and transported (Moser 1985; Bridges and Moser 1986; Magowski and Moser 2003).

Scolytus elm bark beetles also carry phoretic mites on their body surfaces. Recently, we have documented the assemblages of mites phoretic on S. multistriatus and S. pygmaeus in Austria, which consisted of nine species (Moser et al. 2005). These mites included Chelacheles michalskii, Elattoma fraxini (referred to as Elattoma sp. by Moser et al. 2005), nr. Eueremaeus sp., Proctolaelaps eccoptogasteris, Proctolaelaps scolyti, Pseudotarsonemoides eccoptogasteri, Pyemotes scolyti, Tarsonemus crassus, and Trichouropoda bipilis. Here, we extend the knowledge on phoretic mites of Scolytus spp. on elm in central Europe to S. scolytus. The main aim of this study was to record and quantify conidia and ascospores of $O$. novo-ulmi on the various mite species phoretic on the three elm bark beetles $S$. multistriatus, S. pygmaeus, and S. scolytus.

\section{Materials and methods}

Collection of Scolytus elm bark beetles

On May 17, 2002, five stem sections, each about $120 \mathrm{~cm}$ long and $20 \mathrm{~cm}$ in diameter, were cut from a European field 
elm (Ulmus minor) tree, near Güssing $\left(16^{\circ} 20^{\prime} 17^{\prime \prime} \mathrm{E}, 47^{\circ} 04^{\prime}\right.$ 27", 230 m asl), Burgenland, Austria (Moser et al. 2005). This tree had been dying due to DED and was subsequently attacked by two smaller elm bark beetles, $S$. multistriatus and S. pygmaeus. On May 14, 2004, pieces of bark and sapwood containing elm bark beetle breeding galleries were collected from an elm (Ulmus sp.) tree, infested by the larger S. scolytus near Břeclav $\left(16^{\circ} 53^{\prime} 52^{\prime \prime} \mathrm{E}, 48^{\circ} 44^{\prime} 45^{\prime \prime} \mathrm{N}\right.$, $160 \mathrm{~m}$ asl) in the Czech Republic close to the border of Austria. The stem sections and bark pieces were placed in laboratory rearing cages at $20 \pm 1^{\circ} \mathrm{C}$. Offspring beetles of $S$. multistriatus and S. pygmaeus emerged from 28 May to 30 June 2002 (Moser et al. 2005), and those of S. scolytus until the end of May 2004. The beetles were collected periodically and placed in vials containing $70 \%$ ethanol until further use.

Processing of beetles and mounting of mites

Individual beetles including mites still attached to their bodies and any mites in the ethanol sediments were transferred to lactophenol. This was done to clear the body contents of the mites in preparation for mounting them on slides. The mites were then sorted and mounted individually on slides using Berlese's medium (Krantz 1978). Mites still attached to the beetles were counted separately from those that fell off the beetles into the lactophenol and those that became separated from the beetles in the alcohol (Table 1). Mite specimens from S. multistriatus and S. pygmaeus collected in 2002 had earlier been cleared and mounted (Moser et al. 2005). Voucher specimens (slides) of all mite species detected in this study and that by Moser et al. (2005) are maintained in the collection of JC Moser (Southern Research Station, USDA Forest Service) and in those of mite taxonomists (see Moser et al. 2005).

For each species of phoretic mite from $S$. multistriatus, $S$. pygmaeus, and $S$. scolytus all individuals or a sub-sample of mounted specimens (those of Proctolaelaps scolyti from $S$. scolytus) were examined for the presence of fungal spores, especially conidia and ascospores of $O$. novo-ulmi (Upadhyay 1981; Brasier 1991; Table 2). On each of the examined mites, spores were tallied by number and type (conidia or ascospores). In addition, records were made whether spores were present on the body surface and/or in the gut of the mites.

Survival of O. novo-ulmi conidia inside Proctolaelaps scolyti

To test the viability of ingested $O$. novo-ulmi conidia inside guts, single female Pr. scolyti were transferred to cultures of O. novo-ulmi on malt extract agar (MEA, 2\% malt extract, $1.6 \%$ agar) in 9-cm plastic petri dishes. The mites fed on the fungal cultures and propagated quickly on them. After about 3 weeks, individual mites were removed from the cultures and surface-sterilized for $10 \mathrm{~min}$ (experiment 1) or 15 min (experiments 2 and 3 ) in a 1\% sodium hypochlorite solution, in order to kill any spores on the surfaces of their bodies. The mites were then quickly killed in carbon tetrachloride, rinsed in sterile water, and placed on MEA containing $0.01 \%$ cycloheximide and $0.1 \%$ of the antibiotic streptomycin sulfate, a medium selective for Ophiostoma spp. (Harrington 1981). Within a 3-week period the isolation plates were inspected at irregular intervals for the growth of microorganisms (Table 3).

\section{Results}

A total of 27 individuals of $S$. scolytus, consisting of 16 (59\%) male and $11(41 \%)$ female beetles were collected and examined for phoretic mites (Table 1). At least one mite individual was carried by $56.3 \%$ of the male and $72.7 \%$ of the female insects. These values considerably underestimated the presence of mites on individual $S$. scolytus beetles because large numbers of mite specimens became detached from the beetles and were thus present in the alcohol (70.6\% out of the 850 recorded mites) or lactophenol sediments (18.6\%; Table 1). Thus, only $10.8 \%$ of the mites were still present on the bodies of $S$. scolytus beetles. The four mite species $E$. fraxini, Pleuronectocelaeno austriaca, Pr. scolyti, and T. crassus were detected (Table 1). Of the 850 mite individuals recorded, $81.7 \%$ belonged to $P r$. scolyti and another $18 \%$
Table 1 Number of mites phoretic on 16 male and 11 female $S$. scolytus

\begin{tabular}{llllll}
\hline Mite species & $\begin{array}{l}\text { Phoretic } \\
\text { stage }\end{array}$ & \multicolumn{4}{l}{ Number of mite individuals } \\
\cline { 3 - 6 } & & On beetles & Lactophenol sediments & Alcohol sediments & Totals \\
\hline E. fraxini & Female & 0 & 0 & 1 & 1 \\
$\begin{array}{l}\text { Pleuronectocelaeno } \\
\text { austriaca }\end{array}$ & Female & 0 & 0 & 1 & 1 \\
Proctolaelaps scolyti & Female & 82 & 137 & 476 & 695 \\
T. crassus & Female & 10 & 21 & 122 & 153 \\
Total & & 92 & 158 & 600 & 850 \\
\hline
\end{tabular}


Table 2 Conidia, ascospores, and/or hyphae of Ophiostoma novo-ulmi on phoretic mites of S. multistriatus, S. pygmaeus, and S. scolytus

Scolytus species/mite species

Number of phoretic Number $\left(\%^{\mathrm{a}}\right)$ of examined mite individuals with spores or hyphae of $O$. novo-ulmi mites examined

$\begin{array}{lllll}\begin{array}{l}\text { Conidia on } \\ \text { body surface }\end{array} & \begin{array}{l}\text { Ascospores on } \\ \text { body surface }\end{array} & \begin{array}{l}\text { Hyphae } \\ \text { on body }\end{array} & \begin{array}{l}\text { Spores } \\ \text { in gut }\end{array} & \begin{array}{l}\text { Total mites } \\ \text { with spores }^{\mathrm{c}}\end{array}\end{array}$

\begin{tabular}{|c|c|c|c|c|c|c|}
\hline \multicolumn{7}{|l|}{ S. multistriatus $\left(n=144^{\mathrm{d}}\right)$} \\
\hline Chelacheles michalskii & 31 & $0(0.0)$ & $0(0.0)$ & $0(0.0)$ & $0(0.0)$ & $0(0.0)$ \\
\hline E. fraxini $i^{\mathrm{e}}$ & 4 & $0(0.0)$ & $0(0.0)$ & $0(0.0)$ & $0(0.0)$ & $0(0.0)$ \\
\hline nr. Eueremaeus sp. & 1 & $0(0.0)$ & $0(0.0)$ & $0(0.0)$ & $0(0.0)$ & $0(0.0)$ \\
\hline Proctolaelaps eccoptogasteris & 1 & $0(0.0)$ & $0(0.0)$ & $0(0.0)$ & $0(0.0)$ & $0(0.0)$ \\
\hline Proctolaelaps scolyti & 4 & $0(0.0)$ & $0(0.0)$ & $0(0.0)$ & $0(0.0)$ & $0(0.0)$ \\
\hline Pseudotarsonemoides eccoptogasteri & 94 & $2(2.1)$ & $2(2.1)$ & $0(0.0)$ & $0(0.0)$ & $4(4.3)$ \\
\hline Pyemotes scolyti & 1430 & $0(0.0)$ & $0(0.0)$ & $0(0.0)$ & $0(0.0)$ & $0(0.0)$ \\
\hline T. crassus & 22 & $6(27.3)$ & $3(13.6)$ & $2(9.1)$ & $0(0.0)$ & $9(40.9)$ \\
\hline Trichouropoda bipilis & 93 & $0(0.0)$ & $0(0.0)$ & $0(0.0)$ & $0(0.0)$ & $0(0.0)$ \\
\hline Totals for S. multistriatus & 1,680 & $8(0.5)$ & $5(0.3)$ & $2(0.1)$ & $0(0.0)$ & $13(0.8)$ \\
\hline \multicolumn{7}{|l|}{ S. pygmaeus $\left(n=178^{\mathrm{f}}\right)$} \\
\hline Chelacheles michalskii & 10 & $0(0.0)$ & $0(0.0)$ & $0(0.0)$ & $0(0.0)$ & $0(0.0)$ \\
\hline E. fraxini $^{\mathrm{g}}$ & 27 & $0(0.0)$ & $0(0.0)$ & $0(0.0)$ & $0(0.0)$ & $0(0.0)$ \\
\hline nr. Eueremaeus sp. & 1 & $0(0.0)$ & $0(0.0)$ & $0(0.0)$ & $0(0.0)$ & $0(0.0)$ \\
\hline Proctolaelaps eccoptogasteris & 1 & $0(0.0)$ & $0(0.0)$ & $0(0.0)$ & $0(0.0)$ & $0(0.0)$ \\
\hline Proctolaelaps scolyti & 8 & $1(12.5)$ & $1(12.5)$ & $0(0.0)$ & $0(0.0)$ & $2(25.0)$ \\
\hline Pseudotarsonemoides eccoptogasteri & 422 & $0(0.0)$ & $1(0.2)$ & $0(0.0)$ & $0(0.0)$ & $1(0.2)$ \\
\hline Pyemotes scolyti & 1702 & $0(0.0)$ & $0(0.0)$ & $0(0.0)$ & $0(0.0)$ & $0(0.0)$ \\
\hline T. crassus & 24 & $4(16.7)$ & $12(50.0)$ & $3(12.5)$ & $0(0.0)$ & $15(62.5)$ \\
\hline Trichouropoda bipilis & 47 & $0(0.0)$ & $0(0.0)$ & $0(0.0)$ & $0(0.0)$ & $0(0.0)$ \\
\hline Totals for S. pygmaeus & 2,242 & $5(0.2)$ & $14(0.6)$ & $3(0.1)$ & $0(0.0)$ & $18(0.8)$ \\
\hline \multicolumn{7}{|l|}{ S. scolytus $\left(n=27^{\mathrm{h}}\right)$} \\
\hline E. fraxini & 1 & $1(100)$ & $1(100)$ & $0(0.0)$ & $0(0.0)$ & $1(100)$ \\
\hline Pleuronectocelaeno austriaca & 1 & $0(0.0)$ & $0(0.0)$ & $0(0.0)$ & $0(0.0)$ & $0(0.0)$ \\
\hline Proctolaelaps scolyti & $136^{\mathrm{i}}$ & $104(76.5)$ & $36(26.5)$ & $0(0.0)$ & $62(45.6)$ & $104(76.5)$ \\
\hline T. crassus & 153 & $41(16.8)$ & $38(27.9)$ & $0(0.0)$ & $0(0.0)$ & $68(44.4)$ \\
\hline Totals for $S$. scolytus & $291^{\mathrm{j}}$ & $146(50.2)$ & $75(25.8)$ & $0(0.0)$ & $62(21.3)$ & $173(59.5)$ \\
\hline
\end{tabular}

${ }^{\text {a }}$ Percentages refer to the number of mite individuals carrying spores in relation to the number of mites examined, separate for each mite species phoretic on each of the three Scolytus species

${ }^{\mathrm{b}}$ Hyphae occurring in the sporothecae of T. crassus could not unambiguously assigned to $O$. novo-ulmi, but as $O$. novo-ulmi spores were also present, the hyphae were suspected to belong also to this DED fungus

${ }^{\mathrm{c}}$ Totals may not agree because conidia, ascospores, and mycelia may occur on the same individual and mites may contain spores both on their body surface and in the gut

d 56 male and 88 female $S$. multistriatus were examined, but note footnote e for E. fraxini (see Moser et al. 2005)

${ }^{\text {e }}$ Totals from 59 beetles sampled (see Moser et al. 2005)

${ }^{\mathrm{f}} 67$ male and 111 female $S$. multistriatus were examined, but note footnote $\mathrm{g}$ for E. fraxini (see Moser et al. 2005)

${ }^{\mathrm{g}}$ Totals from 52 beetles sampled (see Moser et al. 2005)

${ }^{\text {h }} 16$ male and 11 female $S$. scolytus were examined (see Table 1)

${ }^{\text {i }} 136$ out of 695 (19.6\%) recorded individuals of $P$. scolyti from S. scolytus (see Table 1) were examined for fungal spores

${ }^{\mathrm{j}} 291$ out of 850 (34.2\%) recorded mite individuals from $S$. scolytus (see Table 1) were examined for fungal spores

to $T$. crassus, whereas E. fraxini and $P$. austriaca were each represented by only one individual (Table 1).

Conidia and ascospores of $O$. novo-ulmi and spores of other unidentified fungi were found on four of the ten mite species phoretic on $S$. multistriatus, S. pygmaeus, and $S$. scolytus (Fig. 1). These mites included E. fraxini on S. scolytus, Pseudotarsonemoides eccoptogasteri on S. multistriatus and S. pygmaeus, Pr. scolyti (Fig. 1a-c) 
Table 3 Percentage of successful isolations of bacteria and $O$. novoulmi from surface-sterilized females of Proctolaelaps scolyti that were reared on cultures of $O$. novo-ulmi for about 3 weeks

\begin{tabular}{lllll}
\hline $\begin{array}{l}\text { Growth of } \\
\text { microorganisms }\end{array}$ & $\begin{array}{l}\text { Experiment } \\
1(n=125)\end{array}$ & $\begin{array}{l}\text { Experiment } 2(n=30) \\
\text { Experiment }\end{array}$ & $\begin{array}{l}\text { All three } \\
\text { experiments } \\
(n=185)\end{array}$ \\
\hline $\begin{array}{l}\text { Bacteria only } \\
\text { Bacteria and }\end{array}$ & 24.0 & 20.0 & 6.7 & 20.5 \\
$\begin{array}{c}\text { O. novo-ulmi } \\
\text { novo-ulmi }\end{array}$ & 39.2 & 26.7 & 13.3 & 33.0 \\
$\begin{array}{c}\text { only } \\
\text { No growth of } \\
\text { microorganisms }\end{array}$ & 31.2 & 26.7 & 3.3 & 7.0 \\
\hline
\end{tabular}

$n$ Number of mites examined

on S. pygmaeus and S. scolytus, and T. crassus (Fig. 1d) on all three Scolytus species (Table 2). Thus, two out of the nine mite species phoretic on $S$. multistriatus, three out of the nine species on $S$. pygmaeus, and three out of the four species on S. scolytus carried spores of O. novo-ulmi. Considering all mite specimens investigated, the percentage of individuals with $O$. novo-ulmi spores was much higher for the mites phoretic on S. scolytus (59.5\%) than for those phoretic on $S$. multistriatus and $S$. pygmaeus $(0.8 \%$ each, Table 2).
Proctolaelaps scolyti females, the phoretic stage of this species, are large mites with dorsal shields of specimens measuring approximately $400 \times 320 \mu \mathrm{m}$. Only $12 \mathrm{Pr}$. scolyti females were phoretic on the 322 small-sized S. multistriatus and S. pygmaeus (Moser et al. 2005, Table 2), whereas 695 specimens of this species were recorded on only 27 of the larger-sized S. scolytus (Table 1). Thus, when considering also those individuals that were found in the alcohol and lactophenol sediments, each S. scolytus beetle would on average have carried almost $26 \mathrm{Pr}$. scolyti.

Only two (16.7\%) of the 12 Pr. scolyti females phoretic on $S$. multistriatus and S. pygmaeus carried spores of O. novo-ulmi on their bodies (Table 2). These two mites contained only three ascospores and one conidium, respectively. Of the $695 \mathrm{Pr}$. scolyti from S. scolytus, a sample of 136 individuals was examined for the occurrence of fungal spores. Of these, 104 (76.5\%) carried O. novo-ulmi conidia, and 36 out of those 104 mites with conidia additionally had O. novo-ulmi ascospores attached to their bodies (Table 2). Of the 104 mites with conidia present, nine had one to nine conidia, 56 had ten to 29 conidia, and 39 had 30 to $100+$ conidia on their body surfaces. Of the 36 Pr. scolyti specimens with ascospores, 35 had ten or fewer ascospores, and only one carried more than ten ascospores on the surface of its opisthosoma (Fig. 1a). Of the 136 Pr. scolyti

Fig. 1 Fungal spores on mites phoretic on Scolytus elm bark beetles: a Ascospores of O. novo-ulmi on opisthosomal surface of a Proctolaelaps scolyti female (slide no. 46396), b Hundreds of conidia and ascospores of $O$. novo-ulmi flowing from the squashed bolus of a Proctolaelaps scolyti female (slide no. 46095), c Conidia of O. novo-ulmi and a staurospore conidium in the gut of a Proctolaelaps scolyti individual (slide no. 46099), d Ascospores of $O$. novo-ulmi flowing out from a squashed sporotheca (marked with arrows) of a T. crassus female (slide no. 44426)
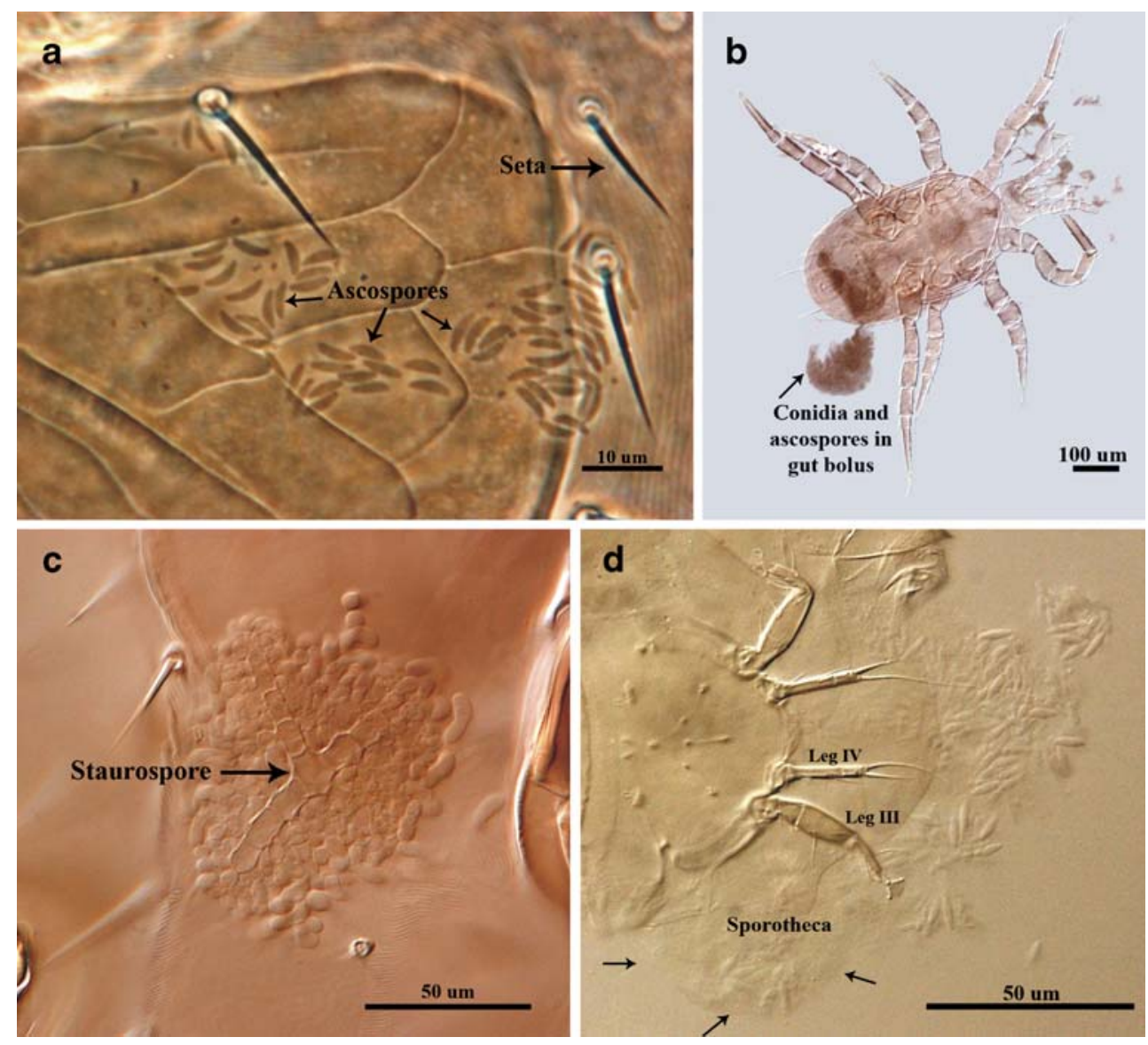
examined, $62(45.6 \%)$ were estimated to contain each 1,000 or more conidia and ascospores in their guts (Fig. 1b-c). A few Pr. scolyti also contained one or more staurospore conidia (Alexopoulos et al. 1996) in their digestive systems (Fig. 1c).

T. crassus females, which are phoretic on Scolytus spp., are small mites, the length and width of specimens averaging approximately $160 \times 100 \mu \mathrm{m}$. Only 46 individuals of this species were phoretic on the 322 adult $S$. multistriatus and S. pygmaeus (Moser et al. 2005, Table 2), whereas 153 specimens occurred on the 27 adults of S. scolytus (Tables 1 and 2). As certain other species of Tarsonemus, T. crassus carried most spores within its paired sporothecae, two pocket-like structures under tergite $\mathrm{C}$ (Magowski and Moser 2003; Fig. 1d), inside which fungal spores are placed, preserved, and transported (Moser 1985). While ascospores, conidia, and likely, also mycelia were present in sporothecae of $T$. crassus individuals phoretic on S. multistriatus and S. pygmaeus, only conidia and ascospores were present on those $T$. crassus taken from $S$. scolytus (Table 2). Of the 46 females of $T$. crassus phoretic on S. multistriatus and S. pygmaeus, 24 (52.2\%) carried spores of $O$. novo-ulmi; 15 specimens carried ascospores and ten had conidia on their bodies (Table 2). Most of the T. crassus specimens with spores carried more than 50 O. novo-ulmi propagules. Of the $153 \mathrm{~T}$. crassus females phoretic on S. scolytus, 68 (44.4\%) contained conidia and/or ascospores of O. novo-ulmi (Table 2). Unlike $T$. crassus individuals phoretic on the smaller-sized S. multistriatus and S. pygmaeus, virtually all specimens of this mite species on $S$. scolytus carried less than five spores and none carried numbers greater than 20 .

The length and width of the dorsal shields of Ps. eccoptogastri females averaged approximately $200 \times$ $100 \mu \mathrm{m}$. This mite species occurred in large numbers on $S$. multistriatus and $S$. pygmaeus, but it was totally absent from $S$. scolytus. Of the 516 specimens of Ps. eccoptogastri phoretic on $S$. multistriatus and $S$. pygmaeus only five (1\%) carried ascospores or conidia of $O$. novo-ulmi (Table 2). Up to 100 O. novo-ulmi ascospores were seen on specimens of Ps. eccoptogasteri, but the spores tended to float from the mite bodies making accurate counts impossible.

$E$. fraxini was the smallest of the four mite species carrying spores of $O$. novo-ulmi. The length and width of the dorsal shields of females of this species averaged approximately $122 \times 80 \mu \mathrm{m}$. No $O$. novo-ulmi spores were seen on the $31 E$. fraxini taken from $S$. multistriatus and $S$. pygmaeus, but the single female of $E$. fraxini from $S$. scolytus harbored about ten each of $O$. novo-ulmi conidia and ascospores (Table 2).

Bacteria and/or $O$. novo-ulmi were isolated from a portion of surface-sterilized $\mathrm{Pr}$. scolyti females that had been reared for about 3 weeks on cultures of $O$. novo-ulmi (Table 3). When combining the results of the three experiments, the DED fungus was isolated from $40 \%$ of the Pr. scolyti individuals, bacteria were isolated from $53.5 \%$ of the specimens, and $39.5 \%$ of the mites did not yield growth of any microorganisms (Table 3). The isolations indicated that at least a portion of conidia of $O$. novo-ulmi ingested by $P r$. scolyti can remain viable.

\section{Discussion}

In this study and our previous one (Moser et al. 2005), a total of ten species of mites were recorded as phoretic associates of the three elm bark beetles $S$. multistriatus, S. pygmaeus, and S. scolytus in central Europe (Tables 1 and 2). Nine of these mite taxa had already been reported previously from S. multistriatus and S. pygmaeus (Moser et al. 2005). Here, we collected a tenth phoretic species, $P$. austriaca, represented by a single specimen on $S$. scolytus (Table 1). S. multistriatus and S. pygmaeus were associated with the same nine phoretic mite species (Moser et al. 2005, Table 2). Likewise, the relative abundance of mites was very similar for both of these elm scolytines, with $P y$. scolyti occurring most frequently and Ps. eccoptogasteri as well as T. bipilis being relatively common (Moser et al. 2005; Table 2). In contrast, only four mite species were found phoretic on $S$. scolytus in the present study (Table 1). Of these, Pr. scolyti was the dominant species and T. crassus occurred in relatively large numbers (Table 2). These two mites occurred only rarely on the two smaller Scolytus species (Moser et al. 2005; Table 2). The two other phoretic mites of S. scolytus, E. fraxini, and P. austriaca were extremely rare as they were each represented by one individual only (Table 1). While E. fraxini was previously recorded as phoretic on $S$. multistriatus and $S$. pygmaeus (Moser et al. 2005; Table 2), P. austriaca is a newly reported mite associate of $S$. scolytus.

Four of the ten mite species phoretic on Scolytus spp. were found to carry spores of the DED fungus $O$. novo-ulmi. Of these, only $3.1 \%$ of the individuals of the generally rare E. fraxini and $1 \%$ of the specimens of the more common Ps. eccoptogasteri had O. novo-ulmi spores on their body surfaces (Table 2). In contrast, large portions of the individuals of Pr. scolyti (71.6\%) and T. crassus (46.2\%) carried conidia and/or ascospores of $O$. novo-ulmi (Table 2), often in high numbers.

Females of E. fraxini, P. eccoptogasteri, and T. crassus have movable cheliceral digits modified for piercing, permitting only ingestion of liquids (Lindquist 1969). Thus, these mites can carry fungal spores only on their body surfaces and, in the case of T. crassus individuals, in their sporothecae. Sporothecae of T. crassus contained conidia, 
ascospores, and likely also hyphae of $O$. novo-ulmi (Table 2), in contrast to Tarsonemus krantzi, which only carries ascospores, but not conidia or hyphae of Ophiostoma minus and Ceratocystiopsis ranaculosus in its sporothecae (Klepzig et al. 2001). The mouthparts of the much larger $P r$. scolyti females include a multidenticulate fixed digit and a tridentate movable digit (Evans 1958), enabling this mite to ingest large numbers of entire fungal spores. As at least a portion of $O$. novo-ulmi conidia ingested by Pr. scolyti can remain viable (Table 3), this mite transports the DED fungus both externally and in its digestive system. Actually, the numbers of ascospores and conidia seen in guts were far greater than those adhering on the bodies of Pr. scolyti, which suggests that, for this mite species, internal transport of fungal spores may be more important than adherence of spores to the body surface.

The feeding habits of phoretic mites of bark beetles are diverse but often poorly known, and this is also the case for the species associated with Scolytus spp. on elm (Moser et al. 2005). Our observations of $O$. novo-ulmi spores on the body surface and in the gut of Pr. scolyti indicate that this mite species is a fungivore. T. crassus most likely also feeds on $O$. novo-ulmi, which would agree well with the biology of other related Tarsonemus species phoretic on bark beetles (Magowski and Moser 2003). In laboratory experiments T. fusari, T. ips, and T. krantzi associated with the southern pine beetle, Dendroctonus frontalis, had positive growth rates when feeding on cultures of $O$. minus and $C$. ranaculosus, spores of which they transport in their sporothecae (Lombardero et al. 2000, 2003). As T. crassus transports only $O$. novo-ulmi spores in its sporothecae, this DED fungus may be of similar nutritional importance for this mite species. As a very low percentage of Pseudotarsonemoides eccoptogasteri and $E$. fraxini carried $O$. novoulmi spores, their dependence on fungi for nutrition is questionable.

The occurrence of conidia and ascospores of $O$. novoulmi on phoretic mites of Scolytus spp. suggests that these minute arthropods, particularly Pr. scolyti and T. crassus, may play a significant role in the processes involved in the transmission of DED. As other mites occurring in the galleries of elm bark beetles (Jacot 1934, 1936; Fransen 1939; Brasier 1978), Pr. scolyti and T. crassus likely spread the fungus within the gallery system and play a role in fertilization of $O$. novo-ulmi protoperithecia, thereby enhancing sexual reproduction. Likewise, these mites most probably spread different fungal genotypes, especially by dissemination of ascospores and may therefore be very important for intermixing of $O$. novo-ulmi genets in the breeding systems of Scolytus spp.

Besides their ecological role in the breeding galleries of elm bark beetles, Pr. scolyti and T. crassus may be directly involved in the transmission of $O$. novo-ulmi, during maturation feeding of Scolytus beetles on twigs and in twig crotches of healthy elm trees. In the feeding grooves initiated by the insects, mite individuals could become detached from the beetles, deposit spores in the phloem, and on the xylem surface and thereby infect Ulmus trees with $O$. novo-ulmi. Beetles can remain for hours, days, and sometimes more than a week in a single feeding groove (Webber and Brasier 1984; Webber 2000, 2004), a time span giving multiple opportunities for mites to become temporarily or permanently separated from the beetles and come in contact with phloem and xylem tissues susceptible to fungal infection.

In contrast to Pr. scolyti and T. crassus, other mites occurring in elm bark beetle galleries (Jacot 1934, 1936; Fransen 1939; Brasier 1978; Doberski 1980) cannot transmit $O$. novo-ulmi spores to healthy elm trees, as they are not phoretic on Scolytus spp. For example, Tyrophagus putrescentiae, occurring in elm bark beetle galleries (Brasier 1978; Doberski 1980), is a ubiquitous acarid tramp species in laboratories throughout the world, a common pest of stored food, and once established, reproduces in large numbers and transmits fungal spores (Griffiths et al. 1959; Hughes 1961). But this mite is likely incapable of transmitting $O$. novo-ulmi from tree to tree due to the absence of an effective phoretic mechanism, such as the deutonymph phoretic stage of most other acarid mites (O'Connor 1982). On very rare occasions, it may have been transported under the elytra of the cerambycid Neacanthocinus obsoletus and the clerid Thanasimus dubius which are common on North American southern pine species (Moser and Roton 1971).

A number of studies have shown that a certain quantity of spores brought by a vectoring elm bark beetle to a feeding groove is required to lead to infection of an elm tree by $O$. novo-ulmi. In inoculation experiments in England, at least 500 to 1,000 conidia were necessary to incite infections on Ulmus procera (Webber 1987; Webber and Gibbs 1989; Sutherland and Brasier 1997), but lower and higher spore loads resulting in infections were reported in other experiments (Webber and Brasier 1994; Faccoli and Battisti 1997; Webber 2000, 2004). Our observations suggest that the phoretic mites Pr. scolyti and T. crassus may greatly increase the spore loads of individual beetles in feeding grooves on healthy elm trees which will enhance the chance for infection by $O$. novo-ulmi to occur.

Among the three Scolytus species examined for phoretic mites, $S$. scolytus is considered as the most important vector of $O$. novo-ulmi, being much more efficient than S. multistriatus and other, smaller Scolytus species (Webber and Brasier 1984; Webber and Gibbs 1989; Webber 1990, 2000). This is because a large portion of $S$. scolytus individuals carry spores of $O$. novo-ulmi and many of these are contaminated with a critical load of at least 500 to 1,000 
spores to incite infections of elm trees (Webber and Brasier 1984; Webber and Gibbs 1989; Webber 1990, 2000). Intriguingly, Pr. scolyti and T. crassus, the only phoretic mites carrying spores of $O$. novo-ulmi consistently and often in high numbers (Table 2), were common mite associates of $S$. scolytus, while they rarely occurred on $S$. multistriatus and S. pygmaeus (Table 1). In addition, none of the individuals of $P r$. scolyti from $S$. multistriatus and only a few from S. pygmaeus carried $O$. novo-ulmi spores (Table 2) and if spores were present, they occurred in very low numbers. In contrast, about the same proportion of $T$. crassus from S. multistriatus and S. pygmaeus (52.2\%) as well as from $S$. scolytus $(44.4 \%)$ had $O$. novo-ulmi spores on their bodies and those from the two smaller Scolytus species carried higher spore loads than those from $S$. scolytus (Table 2). The main difference between the three elm bark beetles was that $T$. crassus was much more abundant on $S$. scolytus than on $S$. multistriatus and S. pygmaeus (Table 2; Moser et al. 2005).

The high efficiency of $S$. scolytus in spreading DED may be partly because of its close association with Pr. scolyti and $T$. crassus and the considerable quantities of hyperphoretic spores of $O$. novo-ulmi they carry. Based on our data, each $S$. scolytus beetle would have carried on an average $25 \mathrm{Pr}$. scolyti and five $T$. crassus individuals. Assuming conservative and low average numbers of 20 $O$. novo-ulmi spores carried internally and/or externally by each Pr. scolyti individual and five spores per T. crassus specimen, the mites phoretic on just a single $S$. scolytus beetle would alone have carried 525 spores, a load that can be sufficient to incite $O$. novo-ulmi infections (Webber 1987; Webber and Gibbs 1989; Faccoli and Battisti 1997; Sutherland and Brasier 1997; Webber 2004).

Our findings raise questions regarding the symbiotic interactions between Scolytus beetles, phoretic mites, and O. novo-ulmi during the phase when the insects breed in the phloem of elm trees. There is evidence that $O$. novo-ulmi is detrimental to larval development, if the fungus and Scolytus larvae come in close physical contact with each other (Webber and Gibbs 1989). In contrast, O. novo-ulmi may be essential for the nutrition of both Pr. scolyti and T. crassus, and it may thus be beneficial for these mites to transmit the fungus. This situation probably resembles the complex relationships between the southern pine beetle, D. frontalis, the phoretic mite T. krantzi, and the blue-stain fungus $O$. minus, where the fungus is a mutualist of the mite, but an antagonist of the insect (Barras 1970; Bridges and Moser 1986; Klepzig et al. 2001; Lombardero et al. 2000; Hofstetter et al. 2006).

While the role of mites in DED has been examined and discussed in previous investigations (Jacot 1934, 1936; Fransen 1939; Brasier 1978; Webber and Brasier 1984), this study is the first one to consider the importance of mites phoretic on Scolytus elm bark beetles for pathogen dispersal. By contributing to the transmission of $O$. novoulmi to elm trees, Pr. scolyti and T. crassus may be important biotic factors for the epidemiology of this destructive vascular wilt disease.

Acknowledgments We thank Clive M. Brasier, Evert E. Lindquist, Alex C. Mangini, Dale S. Starkey, Joan F. Webber, Tatiana Czeschlik, and three anonymous reviewers for comments on earlier versions of the manuscript. Alexandr A. Khaustov identified specimens of E. fraxini. Don A. Griffiths provided advice regarding the bioassays of the gut contents of Proctolaelaps scolyti. Alexander Thuroczy (Dr. Karl Draskovich'sche Forstverwaltung Güssing, Austria) helped to collect the elm stem sections in Austria and Petr Zabrabsky organized the elm material infested by $S$. scolytus in the Czech Republic. Heino Konrad was supported by a grant from the foundation "120 Jahre Universität für Bodenkultur", founded by Rupert Hatschek. The experiments and data collected here comply with the laws of Austria and Czech Republic.

\section{References}

Alexopoulos CJ, Mims CW, Blackwell M (1996) Introductory mycology, 4th edn. Wiley, New York

Barras SJ (1970) Antagonism between Dendroctonus frontalis and the fungus Ceratocystis minor. Ann Entomol Soc Am 63:1187-1190

Brasier CM (1978) Mites and reproduction in Ceratocystis ulmi and other fungi. Trans Br Mycol Soc 70:81-89

Brasier CM (1991) Ophiostoma novo-ulmi sp. nov., causative agent of the current Dutch elm disease pandemic. Mycopathologia $15: 151-161$

Brasier CM (2000) Intercontinental spread and continuing evolution of the Dutch elm disease pathogens. In: Dunn C (ed) The elms - breeding, conservation and disease management. Kluwer, Dordrecht, pp 61-72

Brasier CM, Kirk SA (2001) Designation of the EAN and NAN races of Ophiostoma novo-ulmi as subspecies: their perithecial size differences and geographical distributions. Mycol Res 105:547-554

Brasier CM, Buck K, Paoletti M, Crawford L, Kirk S (2004) Molecular analysis of evolutionary changes in populations of Ophiostoma novo-ulmi. Invest Agrar: Sist Recur For 13:93-103

Bridges JR, Moser JC (1983) Role of two mites in transmission of the blue-stain fungus, Ceratocystis minor. Ecol Entomol 8:9-12

Bridges JR, Moser JC (1986) Relationship of phoretic mites (Acari: Tarsonemidae) to the bluestaining fungus, Ceratocystis minor, in trees infested by the southern pine beetle (Coleoptera: Scolytidae). Environ Entomol 15:951-953

Doberski JW (1980) Mite populations on elm logs infested by European elm bark beetles. $Z$ ang Entomol 89:13-22

Evans GO (1958) A revision of the British Aceosejinae (Acarina: Mesostigmata). Proc Zool Soc Lond 131:177-229

Faccoli M, Battisti A (1997) Observations on the transmission of Ophiostoma ulmi by the smaller elm bark beetles (Scolytus spp.). In: Grégoire J-C, Liebhold AM, Stephen FM, Day KR, Salmon SM (ed) Integrating cultural tactics into the management of bark beetles and reforestation pests. Proceedings of an IUFRO meeting, 1-3 September, 1996, Vallombrosa, Italy. USDA Forest Service General Technical Report NE-236, pp 172-176

Fransen JJ (1939) Iepenziekte Iepenspintkevers an beider bestrijding [Elm disease, elm beetles and their control]. Ph.D. Thesis, Wageningen Agricultural College

Griffiths DA, Hodson AC, Christensen CM (1959) Grain storage fungi associated with mites. J Econ Entomol 52:514-518 
Harrington TC (1981) Cycloheximide sensitivity as a taxonomic character in Ceratocystis. Mycologia 73:1123-1129

Hofstetter RW, Cronin JT, Klepzig KD, Moser JC, Ayres MP (2006) Antagonisms, mutualisms and commensalisms affect outbreak dynamics of the southern pine beetle. Oecologia (Berl) 147:679-691

Hughes AM (1961) The mites of stored food technical. Bulletin no. 9, Ministry of Agriculture, Fisheries and Food, Her Majesty's Stationery Office, London, p. 287

Jacot AP (1934) Acarina as possible vectors of the Dutch elm disease. J Econ Entomol 27:858-859

Jacot AP (1936) Three possible mite vectors of Dutch elm disease. Ent Soc Amer 29:627-635

Kinn DN (1983) Mites as biocontrol agents of bark and sawyer beetles. In: Hoy MA, Cunningham GL, Knutson L (eds) Proceedings of a Conference, 5-7 April, 1982, University of California, Berkeley. Special Publication 3304, Division Natural Resources, Berkeley, CA, pp 67-73

Kirisits T (2004) Fungal associates of European bark beetles with special emphasis on the ophiostomatoid fungi (chapter 10). In: Lieutier F, Day KR, Battisti A, Grégoire J-C, Evans H (eds) Bark and wood boring insects in living trees in Europe, a synthesis. Kluwer, Dordrecht, pp 181-235

Klepzig KD, Moser JC, Lombardero MJ, Hofstetter RW, Ayres MP (2001) Symbiosis and competition: complex interactions among beetles, fungi, and mites. Symbiosis 30:83-96

Konrad H, Kirisits T, Riegler M, Halmschlager E, Stauffer C (2002) Genetic evidence for natural hybridization between the Dutch elm disease pathogens Ophiostoma novo-ulmi ssp. novo-ulmi and Ophiostoma novo-ulmi ssp. americana. Plant Pathol 51:78-84

Krantz GL (1978) A manual of acarology, 2nd edn. Oregon State University Bookstores, Corvallis, OR

Lanier GN, Peacock JW (1981) Vectors of the pathogen. In: Stipes RJ, Campana RJ (eds) Compendium of elm diseases. APS Press, St. Paul, MN, pp 14-16

Lindquist EE (1969) New species of Tarsonemus (Acarina:Tarsonemidae) associated with bark beetles. Can Entomol 101:1291-1314

Lombardero MJ, Klepzig KD, Moser JC, Ayres MP (2000) Biology, demography and community interactions of Tarsonemus (Acarina: Tarsonemidae) mites phoretic on Dendroctonus frontalis (Coleoptera: Scolytidae). Agr and For Entomol 2:193-202

Lombardero MJ, Ayres MP, Hofstetter RW, Moser JC, Klepzig KD (2003) Strong interactions of Tarsonemus mites (Acarina: Tarsonemidae) and Dendroctonus frontalis (Coleoptera: Scolytidae). Oikos 102:243-252

Magowski WL, Moser JC (2003) Redescription of Tarsonemus minimax, and definition of its group of species in the genus Tarsonemus (Acarina: Tarsonemidae) with descriptions of two new species. Ann Entomol Soc Amer 96:345-368

Moser JC (1985) Use of sporothecae by phoretic Tarsonemus mites to transport ascospores of coniferous bluestain fungi. Trans $\mathrm{Br}$ Mycolog Soc 84:750-753

Moser JC, Roton LM (1971) Reproductive compatibility between two widely separated populations of Pyemotes scolyti (Acarina: Pyemotidae). Pan-Pac Entomol 48:97-99
Moser JC, Bogenschütz H (1984) A key to the mites associated with flying Ips typographus in South Germany. Zang Entomol 97:437-450

Moser JC, Kielczewski B, Wisniewski J, Balazy S (1978) Evaluating Pyemotes dryas (Vitzthum 1923) (Acari: Pyemotidae) as a parasite of the southern pine beetle. Internat J Acarol 4:67-70

Moser JC, Perry TJ, Bridges JR, Yin H-F (1995) Ascospore dispersal of Ceratocystiopsis ranaculosus, a mycangial fungus of the southern pine beetle. Mycologia 87:84-86

Moser JC, Konrad H, Kirisits T, Carta LK (2005) Phoretic mites and nematode associates from Scolytus multistriatus and S. pygmaeus (Coleoptera: Scolytidae) in Austria. Agr For Entomol 7:169-177

OConnor BM (1982) Evolutionary ecology of astigmatid mites. Ann Rev Entomol 27:385-409

Pernek M, Hrasovec B, Matosevic D, Pilas I, Kirisits T, Moser JC (2008) Phoretic mites of three bark beetles (Pityokteines spp.) on Silver fir. J Pest Sci 81:35-42

Six DL (2003) Bark beetle-fungus symbioses. In: Bourtzis K, Miller TA (eds) Insect symbiosis. Contemporary topics in entomology series. CRC Press, Boca Raton, London, New York, Washington D.C, pp $97-113$

Sutherland ML, Brasier CM (1997) A comparison of thirteen d-factors as potential biological control agents of Ophiostoma novo-ulmi. Plant Pathol 46:680-693

Upadhyay HP (1981) A monograph of Ceratocystis and Ceratocystiopsis. The University of Georgia Press, Athens

Webber JF (1987) The influence of the $\mathrm{d}^{2}$ factor on survival and infection by the Dutch elm disease pathogen Ophiostoma novoulmi. Plant Pathol 36:531-538

Webber JF (1990) Relative effectiveness of Scolytus scolytus, S. multistriatus and S. kirschi as vectors of Dutch elm disease. Eur J For Pathol 20:184-192

Webber JF (2000) Insect vector behaviour and the evolution of Dutch elm disease. In: Dunn C (ed) The elms-breeding, conservation and disease management. Kluwer, Dordrecht, pp 47-60

Webber JF (2004) Experimental studies on factors influencing the transmission of Dutch elm disease. Invest Agrar: Sist Recur For 13:197-205

Webber JF, Brasier CM (1984) The transmission of Dutch elm disease. A study of the processes involved. In: Anderson JM, Rayner ADM, Walton DWH (eds) Invertebrate-microbial interactions. Joint symposium of the British Mycological society and the British Ecological Society held at the University of Exeter, September 1982. Cambridge University Press, Cambridge, pp 271-306

Webber JF, Gibbs JN (1989) Insect dissemination of fungal pathogens of trees. In: Wilding N, Collins NM, Hammond PM, Webber JF (eds) Insect-fungus interactions. 14th symposium of the Royal Entomological Society of London in collaboration with the British Mycological Society Academic Press, London, pp 161193

Webber JF, Brasier CM (1994) Differential resistance of elms to infection via beetle feeding wounds. In: Report on Forest Research 1994. HMSO London, UK, p. 27 